\title{
PERANAN TURNAMEN BERBASIS ICT DENGAN APLIKASI QUIZIZZ TERHADAP PEMBELAJARAN KIMIA
}

\author{
Sri Wilda Albeta *, Nofianti **, Sri Rahmadani *** \\ * Program Studi Pendidikan Kimia, Fakultas Keguruan dan Ilmu Pendidikan Universitas Riau, \\ Kampus Binawidya KM 12,5, Pekanbaru 28293, Riau, Indonesia. \\ ** SMK N 2 Pekanbaru, Riau, Indonesia. \\ *** SMK Pertanian Terpadu Provinsi Riau, Riau Indonesia.
}

\begin{tabular}{l}
\hline \multicolumn{1}{c}{ Informasi Artikel } \\
\hline Sejarah Artikel: \\
Diterima: $18-01-2020$ \\
Disetujui : 27-01-2020 \\
Dipublikasikan: $28-01-2020$ \\
\hline Keywords: \\
Turnamen berbasis ICT, \\
Quizizz, \\
Chemistry learning \\
\hline
\end{tabular}

\begin{abstract}
A bs trak
Turnamen berbasis ICT dengan aplikasi quizizz berperan terhadap pembelajaran kimia. Peranan ini dilihat dari aspek motivasi dan hasil belajar mahasiswa. Jenis penelitian ini kuasi eksperimen desain "The randomized pre test-post test control group design" dan analisis data menggunakan Uji-t untuk membandingkan kelas kontrol dan eksperimen. Pembelajaran yang melaksanakan turnamen berbasis ICT dengan aplikasi quizizz mampu meningkatkan motivasi dan hasil belajar. Mahasiswa merasa terpacu untuk menjadi yang terbaik. Adanya turnamen dengan aplikasi quizizz menjadikan pembelajaran menjadi menyenangkan, tidak membosankan dan konsep materi pelajaran lebih mudah dikuasai. Selain itu dengan bantuan ICT, mahasiswa bisa melaksanakan turnamen diluar jam perkuliahan sehingga proses pembelajaran dapat dilaksanakan dimana saja dan kapan saja.
\end{abstract}

\begin{abstract}
A b s tract
ICT bases tournament with quizizz application has role play to chemistry leaning study. This role can be seen from motivation and student assessment aspect. This research is design experimental quasi "The randomized pre test-post test control group design” and the data analysis is using t-test for comparing experiment and control class. Learning with this bases can improve the motivation and result of student learning. Students believe that they can be the best in study with this quizizz application. It becomes the wonderful time to study with excited, happy, and the material is easy to understand. Beside that, with ICT function, students can apply this tournament is out of the schedule time to study, so it can be doing at anywhere and anytime.
\end{abstract}

(C) 2020 Universitas Riau

\footnotetext{
*Alamat korespondensi:

e-mail: wilda.albeta@lecturer.unri.ac.id (SWA)

No. Telf: 085271404242
} 


\section{PENDAHULUAN}

Information dan Communication Technology (ICT) pesat berkembang. Semua lapisan masyarakat merasakan manfaat dari perkembangan ICT. Perkembangan ICT dalam dunia pendidikan dapat dirasakan dalam proses belajar-mengajar. Melalui ICT proses belajar-mengajar yang dahulunya terjadwal menjadi lebih fleksibel, dapat dilakukan dimana saja dan kapan saja. Selain itu ICT juga mempermudah komunikasi antara guru dan peserta didik, antar peserta didik sehingga proses pembelajaran dapat berjalan secara optimal. ICT juga memberikan kontribusi dalam pengembangan media pembelajaran, sehingga proses belajar mengajar menjadi lebih menyenangkan dan materi dapat tersampaikan dengan baik.

Perkembangan ICT menjadi tantang bagi guru untuk mampu mengembangkan diri(Copriady, 2014b). Guru yang profesional harus mampu membuka diri mengikuti perkembangan era revolusi industri 4.0 yang erat kaitnya dengan ICT. Guru Professional tidak hanya membelajarkan siswa, tetapi harus mampu mengelola informasi dan lingkungan sekitar sebagai sumber belajar(Ibrahim, 2001). Dengan adanya ICT, informasi dan sumber belajar dapat dikembangkan oleh guru sehingga pembelajaran menjadi lebih menarik, menyenangkan dan materi lebih mudah dipahami peserta didik. Perkembangan ICT dalam dunia pendidikan yang sering digunakan sebagai media pembelajaran berupa e-modul, aplikasi, web dan software yang dirancang khusus untuk pembelajaran dan lain sebagainya. Salah satu manfaat ICT dalam pembelajaran adanya aplikasi Quizizz.

Quiziz merupakan aplikasi pendidikan berbasis game dan turnamen. Menggunakan Quizizz memungkinkan siswa untuk saling bersaing dan memotivasi mereka belajar sehingga hasil belajar bisa meningkat. Siswa mengerjakan quiz dan dapat melihat peringkat langsung mereka di papan peringkat. Quiz dapat dilaksanakan di kelas dan luar jam pelajaran. Melalui Quizizz siswa lebih bersemangat untuk menjadi lebih baik dalam pembelajaran, karena aplikasi ini berbasis turnamen sehingga peserta didik terpicu untuk menjadi pemenang dalam turnamen(Ju, Suo Yan \& Zalika, 2018; Rahayu, Intan Sinta Dewi, \& Pupung, 2019; Zhao, 2019). Turnamen yang dilaksanakan dalam proses pembelajaran membuat peserta didik menjadi lebih bersemangat dan merasa tertantang untuk memenangkan turnamen. Selain itu dengan adanya turnamen peserta didik merasa senang dan tidak bosan dalam pembelajaran. Ada tambahan musik, gambar, video dan lain-lain menjadikan suasana pertandingan lebih menyenangkan(Anjani, Fatchan, \& Amirudin, 2016).

Materi kimia berisikan konsep-konsep yang cukup sulit, di mana terdapat perhitungan kimia dan reaksi kimia yang bersifat abstrak. Bila guru tidak mampu mengatasi permasalahan ini maka peserta didik tidak dapat menguasai materi kimia sehingga tujuan pembelajaran kimia tidak dapat dicapai. Salah satu upaya yang dapat dilakukan untuk mengantisipasi permasalahan ini yakni adanya ICT dalam proses pembelajaran kimia. Dengan ICT guru dapat membuat media pembelajaran kimia sehingga konsep-konsep yang sulit, baik itu berupa perhitungan kimia dan ataupun reaksi kimia yang bersifat abstrak dapat dikuasai peserta didik dengan mudah, menyenangkan dan tidak membosankan.

\section{METODE PENELITIAN}

Jenis penelitian ini kuasi eksperimen desain "The randomized pretest - posttest control group design yang dilaksanakan di Program Studi Pendidikan Kimia FKIP Universitas Riau. Rancangan penelitian dapat dilihatkan (Tabel 1).

Tabel 1. Rancangan Penelitian

\begin{tabular}{|c|c|c|c|c|c|}
\hline \multicolumn{3}{|c|}{ Kelas Kontrol $\left(K_{1}\right)$} & \multicolumn{3}{|c|}{ Kelas Eksperimen $\left(\mathbf{K}_{2}\right)$} \\
\hline Pretest & Posttest & Angket Motivasi & Pretest & Posttest & Angket Motivas \\
\hline
\end{tabular}


Berikut tahapan pelaksanaan penelitian: (1)dipilih dua kelas secara acak. (2) kedua kelas diberikan tes awal (Pre test); (3) dilaksanakan perlakuan untuk kelas kontrol menggunakan pembelajaran klasikal dan kelas eksperimen yang menggunakan turnamen berbasis ICT dengan aplikasi Quizizz; (4) kedua kelas diberikan tes akhir (Post-test); (5) kedua kelas diberikan angket motivasi; (6) melakukan uji statistik. Instrumen penelitian berupa soal objektif dan angket. Soal objektif telah diuji tingkat validitas, indeks kesukaran, daya beda dan reliabilitasnya. Sementara untuk angket telah diuji validitas dan reliabilitasnya. Soal objektif digunakan untuk mengetahui hasil belajar melalui tes awal dan tes akhir. Sementara angket digunakan untuk mengukur motivasi belajar. Data yang terkumpul ditabulasi, kemudian dilakukan uji prasyarat homogenitas dan normalitas sebelum dianalisis uji inferensial parametrik.

Uji inferensial parametrik pada penelitian ini menggunakan uji-t tidak berpasangan untuk mengetahui perbedaan hasil belajar dan motivasi dari kelas kontrol dan kelas eskperimen. Uji-t dilakukan dengan teknik analisis inferensial independent sampel t-test pada program SPSS 20 for windows. Sementara untuk menghitung besar peningkatan hasil belajar digunakan rata-rata gain kemudian dikalikan $100 \%$.

\section{HASIL DAN PEMBAHASAN}

Penelitian ini menggunakan analisis inferensial parametrik sehingga sebelum data dianalisis dilakukan uji prasyarat terlebih dahulu. Data hasil belajar dan motivasi harus memenuhi pra-syarat normalitas dan homogen. Untuk menentukan normalitas antara kelas yang dibandingkan analisis deskriptif yang melibatkan ujian Kolmogorov Smirnov dilakukan. Hasil analisis uji Kolmogorov Smirnov terlihat pada tabel 2.

Tabel 2.Normalitas data hasil belajar dan motivasi mahasiswa

\begin{tabular}{cccc}
\hline Pemboleh ubah & \multicolumn{3}{c}{ Kolmogorov - Smirnov } \\
\cline { 2 - 4 } & Kelas & df & Sig \\
\hline Hasil belajar & Turnamen Quizizz & 36 & 0,65 \\
& Klasikal & 35 & 0,73 \\
Motivasi & Turnamen Quizizz & 36 & 0,87 \\
& Klasikal & 35 & 0,63 \\
\hline
\end{tabular}

Pada tabel 2 hasil analisis menunjukkan masing-masing nilai signifikan $\mathrm{p}>0.05$ untuk uji prasyarat kedua kelas.Ini menunjukkan bahwa kedua kelas ini normal. Artinya, kedua kelas tersebut dapat dilakukan analisis inferensial parametrik untuk mengetahui hasil dari eksperimen yang diberikan kepada kelas tersebut. Uji homogenitas dilakukan pada data pre-test dari kedua kelas (tabel 3). Uji homogenitas bertujuan mengetahui kesamaan varians dari kedua kelas. Bila nilai sig > 0.05 maka kedua kelas memiliki varian yang sama atau homogen.

Tabel 3. Hasil Uji Homogenitas Data

\begin{tabular}{cccc}
\hline Statistik Levene & df1 & df2 & Sig. \\
\hline 0.001 & 1 & 69 & 0,77 \\
\hline
\end{tabular}

Uji prasyarat homogenitas dan normalitas sudah terpenuhi, sehingga dapat dilakukan uji inferensial parametrik yakni uji-t. Uji-t pada penelitian ini digunakan untuk mengetahui perbedaan dari kelas yang diajarkan pembelajaran klasikal dan kelas pembelajaran turnamen berbasis ICT menggunakan Quizizz. Hasil pengujian hipotesis untuk melihat perbedaan hasil belajar dan motivasi 
kedua kelas dengan menggunakan Independen sampel T-test dua pihak pada program SPSS 20 forwindows diperoleh hasil output seperti dalam Tabel 4 :

Tabel 4. Hasil Pengujian Hasil Belajar dan Motivasi

\begin{tabular}{ccc}
\hline & Uji-T & \\
\cline { 2 - 3 } & Sig (2-tailed) & Df \\
\hline Hasil Belajar (Gain) & 0,00 & 69 \\
\hline Motivasi Belajar & 0,00 & 69 \\
\hline
\end{tabular}

Hasil uji-t menggunakan independent $t$-test dengan SPSS 20 diperoleh nilai Sig. (2-tailed) $=0,0$ untuk hasil belajar dan motivasi. Nilai Sig.(2-tailed) 0,0 lebih kecil dari 0,05 sehingga dapat disimpulkan terdapat perbedaan hasil belajar dan motivasi belajar yang signifikan kelas yang diajarkan pembelajaran klasikal dengan kelas yang diajarkan pembelajaran turnamen berbasis ICT menggunakan Quizizz. Dimana bila dilihat dari data deskriptif kelas yang diajarkan pembelajaran turnamen berbasis ICT menggunakan Quizizz memiliki gain yang lebih tinggi daripada kelas yang diajarkan pembelajaran klasikal (gambar 1). Pada kelas yang diajarkan pembelajaran klasikal diperoleh peningkatan hasil belajar sebesar 39,5\%. Sementara untuk kelas yang diajarkan pembelajaran turnamen berbasis ICT menggunakan Quizizz diperoleh peningkatan hasil belajar sebesar $75,2 \%$.

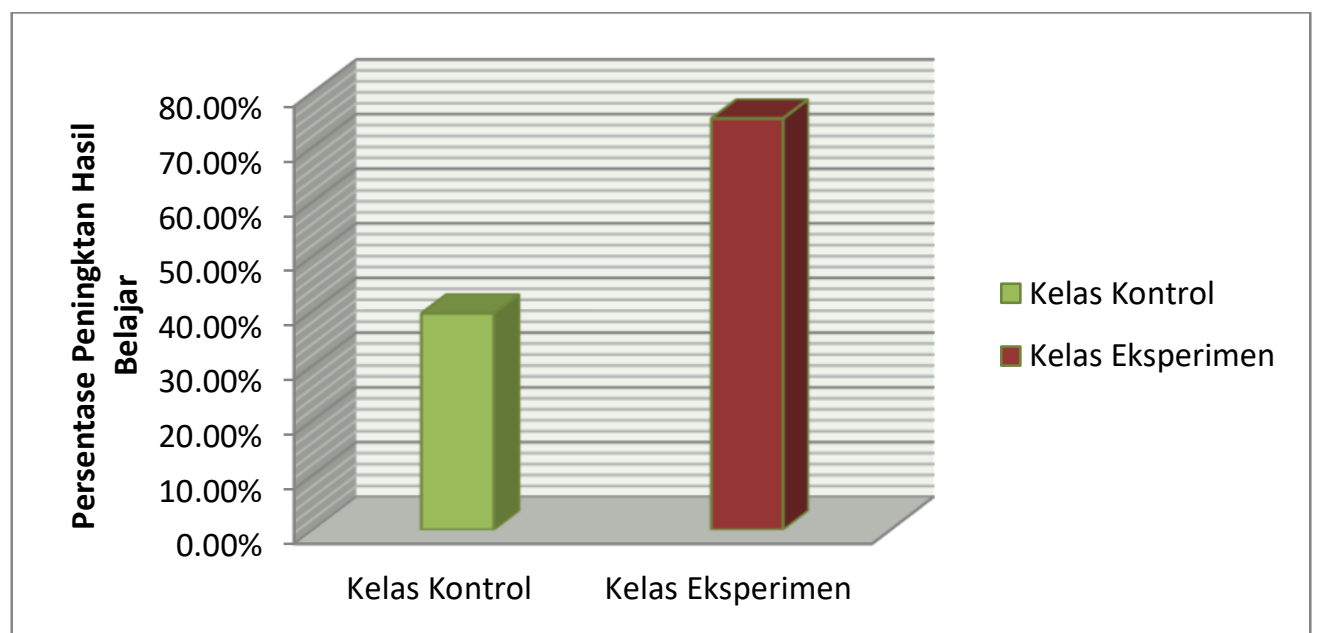

Gambar 1. Perbedaan peningkatan hasil belajar kelas kontrol dan kelas eksperimen

Adanya ICT dalam pembelajaran mempermudah peserta didik untuk menguasai materi dan konsep pembelajaran. Turnamen berbasis ICT menggunakan Quizizz mudah dioperasikan peserta didik dan memiliki tampilan menarik sehingga proses pembelajaran menjadi lebih optimal. Sejalan dengan penelitian yang telah dilakukan Munir(2010) ICT yang mudah dioperasikan menjadikan pembelajaran menjadi efektif dan efisien.

Pada pembelajaran turnamen berbasis ICT menggunakan Quizizz dapat meningkatkan hasil belajar dan motivasi. Peserta didik merasa senang, bersemangat dan terpicu untuk menguasai materi sehingga bisa menjadi yang terbaik dalam turnamen. Hal ini sejalan dengan temuan Copriady(2014a) bahwa dengan adanya ICT dalam pembelajaran berupa aplikasi mampu meningkatkan hasil belajar dan motivasi peserta didik. Temuan yang sama juga diperoleh dari Setiawan, Wigati, \& Sulistyaningsih, (2020) Quizizz mampu meningkatkan hasil belajar. Pembelajaran berbasis turnamen, dalam bentuk games dan kompetisi mampu meningkatkan motivasi dan kinerja peserta(Buchinger, Diego \& Marcelo, 2018; Burguillo, 2010; Chen, Zhi-Hong \& Chen, 2014).Selain itu dengan bantuan 
ICT, peserta didik bisa melaksanakan turnamen di luar jam pelajaran sehingga proses pembelajaran dapat dilaksanakan dimana saja dan kapan saja.

\section{KESIMPULAN}

Penggunaan turnamen dalam pembelajaran menjadikan suasana pembelajaran menjadi lebih optimal. Peserta didik bersemangat untuk belajar hingga mampu menguasai materi dan konsep kimia. Dengan adanya turnamen berbasis ICT menggunakan Quizizz peserta didik bersemangat untuk menjadi yang terbaik. Melalui turnamen berbasis ICT menggunakan Quizizz peserta didik termotivasi untuk belajar lebih giat hingga mampu menguasai materi dan berusaha memenangkan turnamen. Dengan adanya turnamen berbasis ICT menggunakan Quizizz pembelajaran menjadi lebih menyenangkan, tidak membosankan, mampu meningkatkan hasil belajar, motivasi belajar peserta didik dan dapat dilaksanakan di luar jam pelajaran sehingga proses belajar mengajar dapat dilaksanakan dimana saja dan kapan saja.

\section{DAFTAR PUSTAKA}

Anjani, K., Fatchan, A., \& Amirudin, A. (2016). Pengaruh Pembelajaran Berbasis Turnamen Dan Games Terhadap Motivasi Belajar Siswa. Jurnal Pendidikan - Teori, Penelitian, Dan Pengembangan, 1(9), 1787-1790. https://doi.org/10.17977/jp.v1i9.6812

Buchinger, Diego \& Marcelo, da S. H. (2018). Guidelines for designing and using collaborativecompetitive serious games. Computers \& Education, 118, 133-149.

Burguillo, J. C. (2010). Using game theory and competition-based learning to stimulate student motivation and performance. Computers \& Education, 55(2), 566-575.

Chen, Zhi-Hong \& Chen, S. Y. (2014). When educational agents meet surrogate competition: Impacts of competitive educational agents on students' motivation and performance. Computers \& Education, 75, 274-281.

Copriady, J. (2014a). Penerapan SPBM yang Diintegrasikan dengan Program Exe Learning Terhadap Motivasi Hasil Belajar Mahasiswa Pada Mata Kuliah Kimia Dasar. Jurnal Pendidikan, 5(2), 95105.

Copriady, J. (2014b). Self - Motivation as a mediator for teachers' readiness in applying ICT in teaching and learning. Turkish Online Journal of Educational Technology, 13(4), 115-123. https://doi.org/10.1016/j.sbspro.2015.01.529

Ibrahim, M. S. (2001). Perkembangan professionalisme guru: satu tuntutan dan satu kemestian. Seminar Nasional Perguruan dan Kepimpinan Pendidikan ke-10. In Institut Aminuddin Baki. Genting Highlands.

Ju, Suo Yan \& Zalika, A. (2018). Implementing Quizizz as Game Based Learning in the Arabic Classroom. European Journal of Social Science Education and Research, 5(1), 194-198.

Munir, M. (2010). Penggunaan Learning Management System (Lms) Di Perguruan Tinggi: Studi Kasus Di Universitas Pendidikan Indonesia. Jurnal Cakrawala Pendidikan, 1(1), 109-119. https://doi.org/10.21831/cp.v1i1.222

Rahayu, Intan Sinta Dewi, \& Pupung, P. (2019). The Use of Quizizz in Improving Students' Grammar Understanding through Self-Assessment. Eleventh Conference on Applied Linguistics (CONAPLIN 2018). Atlantis Press.

Setiawan, A., Wigati, S., \& Sulistyaningsih, D. (2020). Implementasi Media Game Edukasi Quizizz Untuk Meningkatkan Hasil Belajar Matematika Materi Sistem Persamaan Linear Tiga Variabel Kelas X Ipa 7 Sma Negeri 15 Semarang Tahun Pelajaran 2019 / 2020. Seminar Nasional Edusainstek FMIPA UNIMUS 2019 ISBN, ISBN, 2020, 167-173.

Sunyono, Sunyono, I. Wayan Wirya, and G. S. (2009). Identifikasi masalah kesulitan dalam pembelajaran kimia SMA kelas X di propinsi Lampung. Jurnal Pendidikan MIPA, 10(2), 9-18.

Zhao, F. (2019). Using Quizizz to Integrate Fun Multiplayer Activity in the Accounting Classroom. International Journal of Higher Education, 8(1), 37-43. 
Albeta et al., 2020 JPK UNRI 5(1): 11-15 